\title{
A Látrányi Puszta Temészetvédelmi Terület puhatestü (Mollusca) faunájának felmérése
}

\author{
HÉra ZOLTÁN
}

\author{
H-7400 Kaposvár, Hemann O. 59., Hungary
}

HÉra Z.: Basic malacological (Mollusca) research of the Látrányi Puszta Nature Conservation Area. Abstract: The purpose of this paper is to describe the mollusc fauna of the Látrányi Puszta Nature Conservation Area which covers 207 hectares and is significant for its high bio-diversity. The study also intends to point out the zoogeographically valuable species, and shows the effects of the destruction of the environment. It also gives suggestions on how to save natural values and how to develop methods to sustain the existing habitats. Due to the lack of available literature on the area, the data of earlier samplings and the material from the neighbouring collecting sites formed the base of the comparison.

Key words: habitats, protected species invasive molluscs

\section{Bevezetés}

Külső-Somogy a Dunántúli-dombságnak a Balatontól délre elterülő tájegysége, amely szerkezetileg, morfológiailag, éghajlati, talajtani szempontból legalább annyira elkülönül Belső-Somogy középtájától, mint flórája és faunája tekintetében. A 67-es számú föút, Látrány, Tetves-patak, Somogytúr település által határolt területen a felszín alacsony, északkeleti irányba lejt, legmagasabb pontján 143,1 méter, legalacsonyabb pontján $116,8 \mathrm{~m}$ tengerszint felett.

Néhány méterrel a felszín alatt felsőpannon balatoni üledékek húzódnak, bennük Melanopsis fajok és Limnocardium töredékek találhatók. (A 2001. évben a területen gázvezetéket telepítettek, ennek földmunkái nyomán ezek a rétegek is megfigyelhetöek voltak, a közeli Disznós-kertben a fosszíliák viszont a felszínen láthatók.) A terület nagy részét negyedidőszaki homok borítja, kisebb arányban a karbonátos homokon kialakult humuszos erdőtalaj, illetve rétláp talaj is elöfordul.

Éghajlatában szubmediterrán hatások érvényesülnek, tele viszonylag enyhe, a kitettség és a borítottság arányában a felmelegedés mértéke jelentős eltéréseket mutat. Bár Külső-Somogy nyári csapadékeloszlása szeszélyes területi előfordulású, Látrány térsége bőséges csapadékot kap (REÖTHY 1986).

Mivel a terület a Somogytúr - Orci meridionális völgyben húzódik, keletről a Karádihátság, nyugatról a Gamási-hát határolja, így észak-dél irányban nyitott, ezért különösen fontos az a körülmény, hogy éves viszonylatban az északias illetve délies szelek aránya mintegy $50 \%$, míg a keleti és nyugati szelek 30\%-os gyakoriságúak. Nyáron a kis sebességü szelek közül a déli, délnyugati szelek, míg az erősebb szelek közül az északias szelek az uralkodóak. Télen ez erősebb és gyengébb iszelek is jellemzően északiasak, míg tavasszal és ősszel a délkeleti szelek. Ôsszel, szeptember végén és október elején a szubmediterrán hatást közvetítő délies szelek aránya megnő. A szélcsendes időszak az egész évinek mintegy 20\%-a. (BACSÓ 1959; ÁDÁM et al. 1981)

A meridionális helyzetü völgy legnagyobb vízfolyása a Tetves-patak, amely Balatonszemesnél torkollik a Balatonba. A Vadé-puszta melletti völgyi vízválasztója 
mintegy $25 \mathrm{~km}$ távolságra van a tótól, Vízgyüjtő területének nagysága mintegy $94 \mathrm{~km}^{2}$, közepes vízhozama 0,2 $\mathrm{m}^{3} / \mathrm{sec}$ (ERDÉLYI 1961-1962). A Tetves-patakba torkolló kisebb vizek szélsőséges vízjárásúak. A kora tavaszi időszakban bövebb vizüek, a nyári hónapokban gyakorta kiszáradnak.

A kutatás célja a 223,58 hektáros kiterjedésü, rendkívül mozaikos élővilágú Látrányi Puszta Természetvédelmi Terület puhatestü (Mollusca) faunájának megállapítása, a zoológiai értéket jelentő fajok körének meghatározása, a terület élövilágát veszélyeztető hatások kimutatása és a természeti értékek megőrzését, az élőhelyek fenntartását célzó kezelési módokhoz ajánlások megfogalmazása. A területröl nem állnak rendelkezésre irodalmi adatok, így csak a korábbi évek terepi adatai, valamint a közeli gyưjtési helyek anyagai szolgáltatnak csekély összehasonlítási alapot.

\section{Anyag és módszer}

A csiga és kagyló fauna mintavételezése a malakológiai kutatásokban általánosan alkalmazott mintavevő módszerekkel történt:

Egyeléses mintavétel valamennyi mintavételi területen.

Házatlan csigák helyszíni megfigyelése.

Fühálózás, az anyag helyszíni szétválogatása.

A Tetves-patak és a Vízgyüjtő-árok fluviatilis uszadékának (továbbiakban: molluszkum) begyüjtése, szárítás utáni válogatása.

Iszapminta vétele a Tetves-patakból és a Vízgyüjtő-árokból, majd az anyag $1 \mathrm{~mm}$ lyukbőségü szitán való szürése, szétválogatása.

Talajfelszíni törmelék gyüjtése - mintavételi pontonként $1 \mathrm{dm}^{3}$-, majd ennek szárítás utáni válogatása.

A gyüjtött anyag a Somogy Megyei Múzeum Természettudományi Osztályának gyüjteményében került elhelyezésre.

\section{Eredmények}

A 2001. évi faunakutatás során 12 mintavételi területről 63 faj összesen 3249 példánya került elö (1. táblázat). Kettő további faj jelenléte az 1999. évi gyüjtés alapján bizonyosra vehetö: a Zebrina detrita (Müller, 1774) 2 fiatal példánya a terület nyugati felének tölgyes sztyepprétjéről fühálózással került elö, az Acanthinula aculeata (Müller, 1774) üres héját a Vízgyüjtő-árok uszadéka tartalmazta. Így az ismertté vált fajok száma 65. Ezek többsége a természetvédelmi területen él, 7 faj azonban csak Tetves-patak által szállított molluszkumból került elö. Ezek az alábbi fajok: Bithynia tentaculata, Bathyomphalus contortus, Sphyradium doliolum, Cochlodina laminata, Macrogastra ventricosa, Trichia hispida, Pisidium amnicum. A Sphyradium doliolum feltehetöen fosszilis példány, bár a fajt KLEIN (1992) Külső-Somogyból említi. A többi faj számára az élőhelyek egy része alkalmasnak látszik, megtelepedésük (előfordulásuk?) valószínúsíthető. Feltünő a Planorbidae család fajainak alacsony száma, amelynek oka a terület erös vízvesztése lehet. A vízi fauna megmaradása szempontjából kedvezőtlen esemény a Potamopyrgus antipodarum megtelepedése a Tetves-patak és a Vízgyüjtỏ árok vízében. A gyomosodó szegélytársulásokban már jelen van az Arion lusitanicus meztelencsiga. Nem került elö a faunából a Vitrina pellucida (Müller, 1774), amely Külső-Somogy más arid, homoktalajú területén gyüjthetö állat, és többféle erdőtársulásban él (KLEIN 1992). 


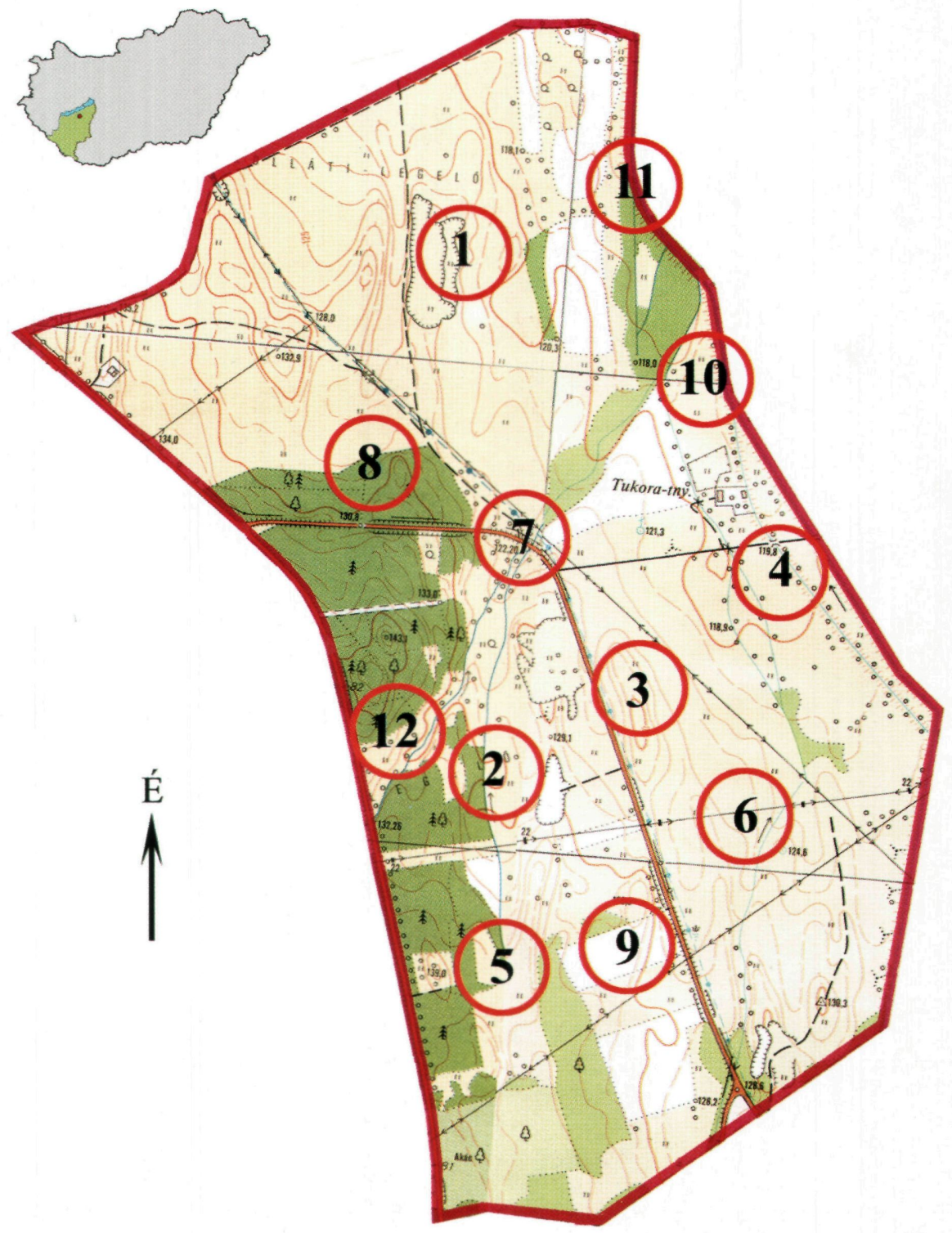

1. ábra: Mintavételi helyek a természetvédelmi területen 


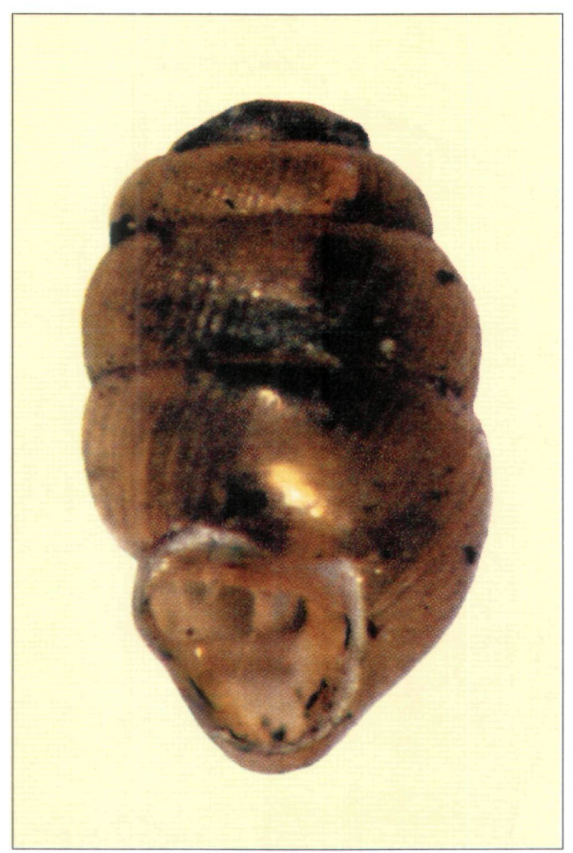

2. ábra: Vertigo angustior Jeffreys, 1830

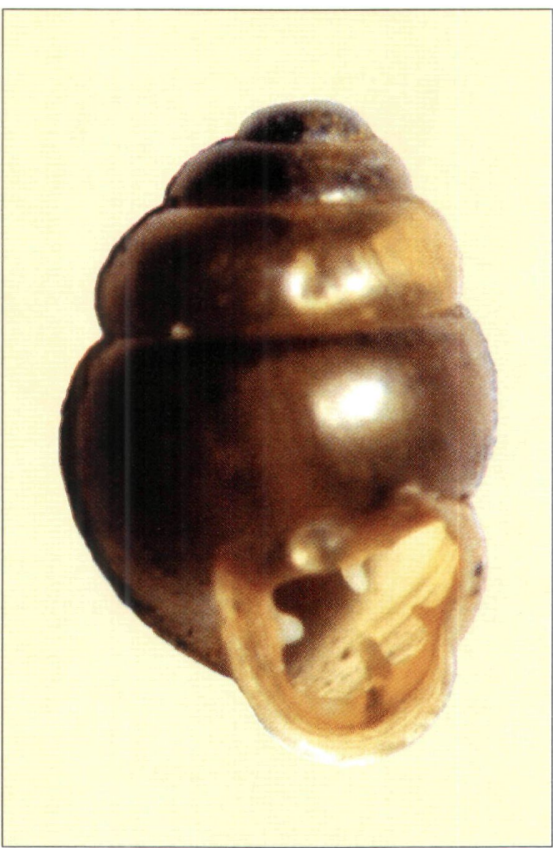

3.ábra: Vertigo moulinsiana (Dupuy, 1849) 
1. táblázat: A mintákból elökerült fajok

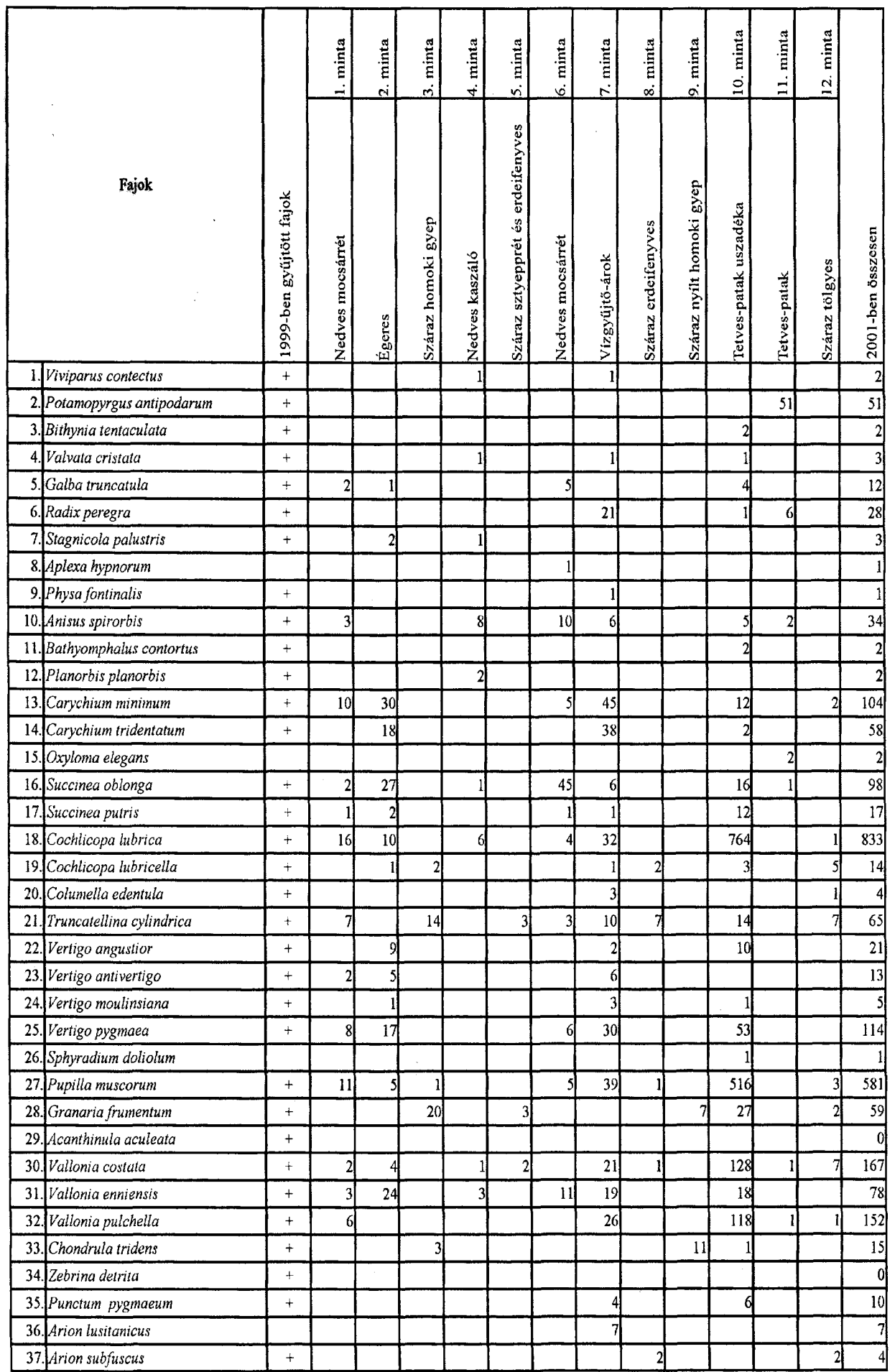


1. táblázat folytatása

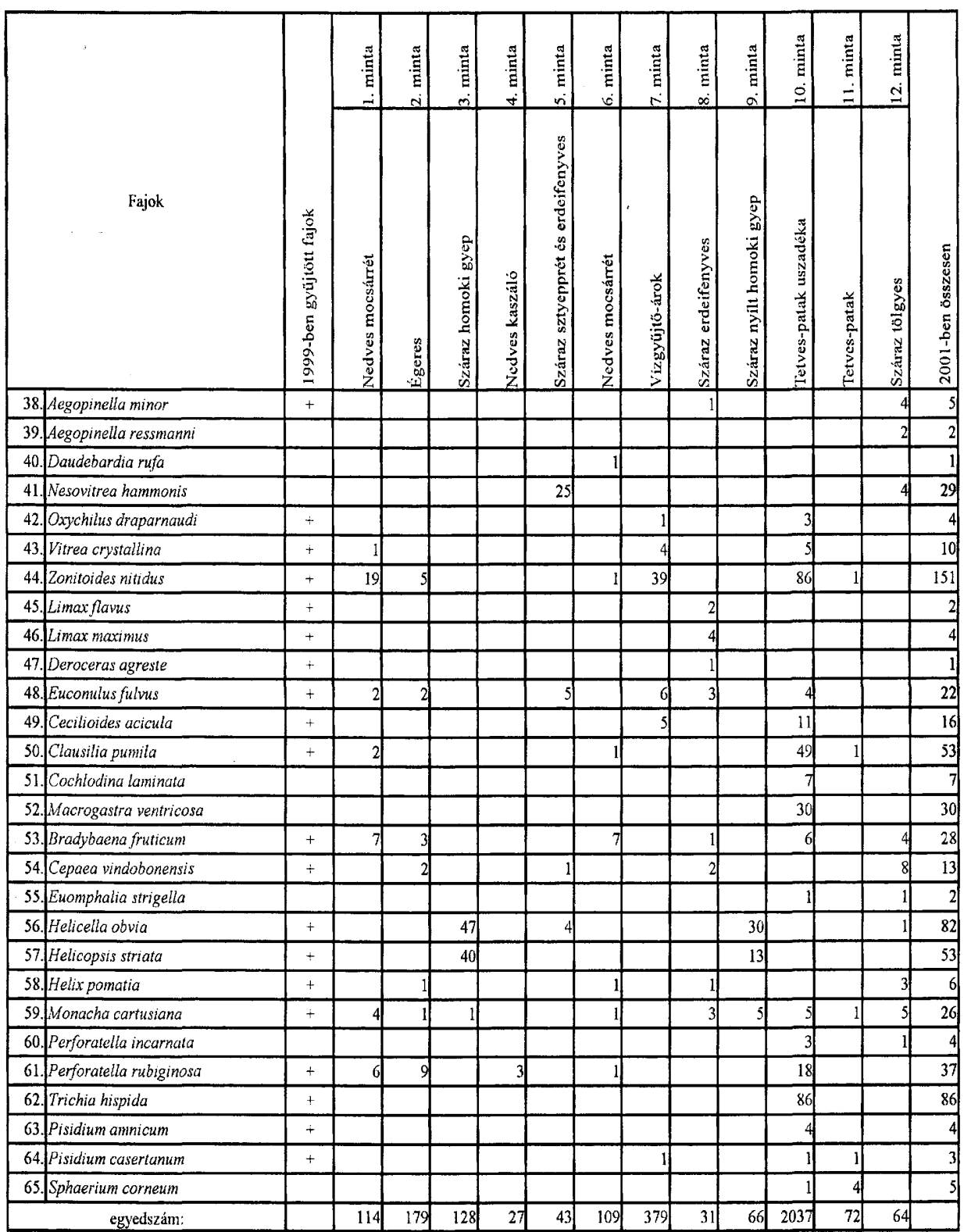




\section{2. táblázat: A védett fajok természetvédelmi megítélése a különböző fajszintü listákon}

\begin{tabular}{|l|c|c|c|}
\hline Faj: & Vertigo angustior & Vertigo moulinsiana & Helix pomatia \\
\hline Hazai védelme: & védett & védett & védett \\
\hline Eszmei értéke: & $2000 \mathrm{Ft}$ & $2000 \mathrm{Ft}$ & $2000 \mathrm{Ft}$ \\
\hline Védetté nyilvánítás éve: & 1993 & 2001 & 1993 \\
\hline IUCN Red List 1990 & Veszélyeztetett (V) & Veszélyeztetett (V) & Ritka (R) \\
\hline IUCN Red List 1994 & Információ hiányos (K) & Nincs a listán (NL) & - \\
\hline IUCN Red List 1996 & $\begin{array}{l}\text { Alacsony kockázatú (LR/cd -) } \\
\text { védelem függő faj }\end{array}$ & $\begin{array}{l}\text { Alacsony kockázatú (LR/ cd -) } \\
\text { védelem függő faj }\end{array}$ & nem veszélyeztetett \\
\hline IUCN Red List 2000 & $\begin{array}{l}\text { Alacsony kockázatú (LR/cd -) } \\
\text { védelem függő faj }\end{array}$ & $\begin{array}{l}\text { Alacsony kockázatú (LR/ cd -) } \\
\text { védelem függő faj }\end{array}$ & + \\
\hline CORINE Biotopes & + & + & \\
\hline
\end{tabular}

\section{A területröl elökerült puhatestüek fajlistája:}

\section{GASTROPODA}

Viviparidae

Viviparus contectus (Millet, 1813)

\section{Hydrobiidae}

Potamopyrgus antipodarum (Gray, 1843)

Bithyniidae

Bithynia tentaculata (Linnaeus, 1758)

Valvatidae

Valvata cristata Müller, 1774

Lymnaeidae

Galba truncatula (Müller, 1774)

Radix peregra (Müller, 1774)

Stagnicola palustris (Müller, 1774)

Physidae

Aplexa hypnorum (Linnaeus, 1758)

Physa fontinalis (Linnaeus, 1758)

\section{Planorbidae}

Anisus spirorbis (Linnaeus, 1758)

Bathyomphalus contortus (Linnaeus, 1758)

Planorbis planorbis (Linnaeus, 1758)

\section{Carychiidae}

Carychium minimum Müller, 1774

Carychium tridentatum (Risso, 1826)

\section{Succineidae}

Oxyloma elegans (Risso, 1826)

Succinea oblonga Draparnaud, 1801

Succinea putris (Linnaeus, 1758)

\section{Cochlicopidae}

Cochlicopa lubrica (Müller, 1774)

Cochlicopa lubricella (Porro, 1838)
Vertiginidae

Columella edentula (Draparnaud, 1805)

Truncatellina cylindrica (Férussac, 1807)

Vertigo angustior Jeffreys, 1830

Vertigo antivertigo (Draparnaud, 1801)

Vertigo moulinsiana (Dupuy, 1849)

Vertigo pygmaea (Draparnaud, 1801)

Orculidae

Sphyradium doliolum (Bruguičre, 1792)

Pupillidae

Pupilla muscorum (C. Linnaeus, 1758)

Chondrinidae

Granaria frumentum (Draparnaud, 1801)

Valloniidae

Acanthinula aculeata (Müller, 1774)

Vallonia costata (Müller, 1774)

Vallonia enniensis (Gredler, 1856)

Vallonia pulchella (Müller, 1774)

Enidae

Chondrula tridens (Müller, 1774)

Zebrina detrita (Müller, 1774)

Endodontidae

Punctum pygmaeum (Draparnaud, 1801)

Arionidae

Arion lusitanicus Mabille, 1868

Arion subfuscus (Draparnaud, 1805)

Zonitidae

Aegopinella minor (Stabile, 1864)

Aegopinella ressmanni (Westerlund, 1833)

Daudebardia rufa (Draparnaud, 1805)

Nesovitrea hammonis (Ström, 1765)

Oxychilus draparnaudi (Beck, 1837)

Vitrea crystallina (Müller, 1774)

Zonitoides nitidus (Müller, 1774) 
Limacidae

Limax flavus Linnaeus, 1758

Limax maximus Linnaeus, 1758

Agriolimacidae

Deroceras agreste (Linnaeus, 1758)

Euconulidae

Euconulus fulvus (Müller, 1774)

Ferussaciidae

Cecilioides acicula (Müller, 1774)

Clausiliidae

Clausilia pumila Pfeiffer, 1828

Cochlodina laminata (Montagu, 1803)

Macrogastra ventricosa (Draparnaud, 1801)

Bradybaenidae

Bradybaena fruticum (Müller, 1774)
Helicidae

Cepaea vindobonensis (Férussac, 1821)

Euomphalia strigella (Draparnaud, 1801)

Helicella obvia (Menke, 1828)

Helicopsis striata (Müller, 1774)

Helix pomatia Linnaeus, 1758

Monacha cartusiana (Müller, 1774)

Perforatella incarnata (Müller, 1774)

Perforatella rubiginosa (Schmidt, 1853)

Trichia hispida (Linnaeus, 1758)

\section{BIVALVIA}

Shaeriidae

Pisidium amnicum (Müller, 1774)

Pisidium casertanum (Poli, 1791)

Sphaerium corneum (Linnacus, 1758)

\section{A fajok védelmének helyzete}

A területen élö puhatestüek közül 3 faj védett (2. táblázat). Mindhárom szerepel a veszélyeztetett fajok adatbázisában (Doc. URL 1.). A Vertigo fajok fennmaradása csak élöhely megörzési programokkal biztosítható. A Helix pomatia veszélyeztetettségének megitéléséhez nem áll elegendő adat rendelkezésre. Fokozottan védett molluszka nem él a térségben.

\section{$A$ védett fajok bemutatása}

1. Vertigo angustior Jeffreys, $1830=$ Balogcsiga

Az állat leírása: Háza tojásdad alakú, balra csavarodó. Főként középső kanyarulatain jól megfigyelhető finom, szabályos vonalkázottsága. Héja fénylö, sárgás vagy vörösesbarna színü. Csúcsrésze tompa, kanyarulatai kevéssé domborúak, számuk 5-6. Utolsó kanyarulatán a szájadéktól kiindulva egyre sekélyebbé váló barázda fut hátrafelé, a barázda alatt és a szájadék mögött a ház erősen megduzzadt. Szájadéka csaknem szív alakú, szegélye éles, kissé kihajló, benne rendesen 4 fogszerü lemez található. Az állat érdekessége, hogy fajrokonaihoz hasonlóan csak szemtartói vannak, tapogatói nincsenek. Lába rövid, talpa három pásztára tagolódik. Házát ferdén fölfelé tartva hordja. Hímnős állat. Átlagos méretei: magassága $1.5-2 \mathrm{~mm}$, szélessége 0.9-1 mm.

Életmódja: A mészben gazdag élőhelyeket kedveli. Közép-európai lelőhelyei nedves élöhelyek, mocsarak, tópartok, égerlápok, lápok. A talaj felszínén, növények és törmelékek között él.

A faj elöfordulása: Európa mérsékelt övi részében él Portugáliától a Kaukázusig. A síkság és az alacsony hegyvidék állata. Hazánkból elszórt előfordulási adatai vannak a Dunántúli-középhegységböl, az Északi-középhegységből, az Alföld egyes pontjairól és délnyugati dombvidékeinkről.

\section{Vertigo moulinsiana (Dupuy, 1849) $=$ Nagy hasascsiga}

Az állat leírása: Háza tojásdad, 5 meglehetősen domború kanyarulattal, amelyek közül az utolsó jelentősen megnövekedik, akár a ház magasságának kétharmadát is kiteheti. Szájadéka kissé háromszögletü, szívet formázó, benne 4, ritkábban 5 fog látható. 
Szájadékának pereme finoman kihajló, mögötte erős tarkóduzzanat, belsejében fejlett fehér zománcduzzanat van. A héj színe sárgás- vagy vörösesbarna, áttetszö, erös fényü, sima felületü.

Átlagos méretei: magassága 2,0 - 2,7 mm, szélessége $1,5 \mathrm{~mm}$.

Életmódja: A vizes élőhelyek lakója. Tipikus a mocsaras, ingoványos területeken, a nádasokban és a sással borított tó-vagy folyópartokon, felmászik többféle növényfaj (Typha, Iris, Glyceria, stb.) leveleire illetve szárára, nem ritkán $30 \mathrm{~cm}$-rel a talaj felett, vagy a víz fölé hajló hajtásokon tartózkodik. A növényeken élösködő gombafonalakkal táplálkozik (Soós, 1943). A nyirkos erdőket, bozótosokat is kedveli, ősszel és kora tavasszal a földön, moha, lehullott lomb és törmelék alatt él. A gyakran kaszált vagy legeltetett területen nem marad meg (PoKRYSZKo 1990)!

A faj előfordulása: Atlanti-mediterrán (talán holarktikus) faj, de fellelhető a Brit-szigetek déli részén, Dániában és Svédország illetve Litvánia legdélibb területein. A faj elterjedésének déli határa nem pontosan ismert.

3. Helix pomatia Linnaeus, 1758 = Éti csiga

$\mathrm{Az}$ állat leírása: Háza gömbded-kúpos, 5 kanyarulatú, enyhén kiemelkedő tekerccsel és tompa csúccsal. Héja erős, szabálytalanul vonalkázott, gyenge fényü. Alapszíne lehet fehéresszürke, sárgásbarna vagy sötétebb barna, amelyet jellemzően 5 öv díszít, de az övek színezete gyakran halvány és határaik is egybemosódnak. Köldöke nagyon szük, a ráhajló perem csak egy keskeny rést hagy szabadon belöle. Szájadéka tág, kerekded, szegélye megvastagodott, ajakduzzanata fehér vagy ibolyás árnyalatú.

Átlagos méretei: magassága $27-49 \mathrm{~mm}$, szélessége $39-49 \mathrm{~mm}$.

Életmódja: Bozótosokban, ligetekben, ritkás erdőkben, aljuknál növényzettel benőtt sziklákon és falakon, valamint kertekben él. Egyaránt elöfordul nedves, nyirkos és szárazabb helyeken, a közvetlen napfényt kerüli, így a gyér növényzetü, melegebb lankákon ritkább. Főként a talajon tartózkodik, de megmássza az erősebb lágyszárú növényeket is. Fákra, falakra, sziklákra csak alacsony magasságig megy fel. Házát télen szilárd, fehér színü fedővel (epiphragma) és több hártyás lemezzel zárja le.

A faj előfordulása: Délkelet- és közép-európai faj, előfordul Skandinávia déli részén, a Balkán északi részén Macedóniáig. Nyugat-európai elterjedése jórészt elhurcoláson, illetőleg mesterséges megtelepítésen alapszik, mert a kolostorok és várak körül étkezési célokra tenyésztették. Főként az alacsonyabb fekvésü helyeket, síkságokat és dombvidékeket kedveli, magasabb hegyvidékeken ritkább. Nálunk általánosan elterjedt, de állományainak nagysága erősen eltérő, $s$ helyenként a kíméletlen gyüjtés miatt vészesen megritkult. A vizsgált terület valamennyi nedves élőhelyén megtalálható.

\section{A fauna invázív fajai}

Behurcolt, egyértelműen idegen eredetü, terjedőképes, potenciálisan vagy ténylegesen is agresszív faunaelemek a területen:

Potamopyrgus antipodarum (Gray, 1843)

A faj világszerte terjed, így hazánkban is mind több felszíni vízfolyásban előfordul. Igen ellenálló faj. Detritusszal és algákkal táplálkozik. Jól türi a vízszennyezést és az időszakos kiszáradást is elviseli. Hím példányait még nem észlelték, szüznemzéssel szaporodik. Terjedése jelenlegi ismereteink szerint nem megakadályozható.

A Tetves-patakban és mellékvizeiben egyaránt jelen van.

Arion lusitanicus Mabille, 1868

Délnyugat-Európából és az Ibériai-félszigetről ismert faj. Hazánkban bizonyíthatóan 1986 óta van jelen (VARGA et al., 1995).

Terjedésének megakadályozására hatékony módszer nem ismert. Rejtett életmódot folytat. Estétől hajnalig jár táplálkozni, az erős fényt, a tüző napot és a szelet kerüli., bár 
kevéssé érzékeny rá, mint más meztelencsiga fajok. Kevés csigapredátor fogyasztja az állatot keserü íze, rágóssága és bőséges nyálkatermelése miatt (GRABER \& SUTER 1995).

Elsősorban növényi táplálékot fogyaszt - ebből fakadó a kártétele is. Évente több peterakási időszaka is van.

A Tetves-patak mellékéről került elő. Populációjának nagysága várhatóan rohamosan növekedni fog.

\section{Az élöhelyek jellemzése, állatföldrajzi vonatkozások}

1. és 6. mintaterület: A homokbuckák között kialakult mélyedésekben a pannon üledék fölött kialakult vizes élöhelyen mocsári vegetáció található. Sajátosságaiból adódóan változó vízboritású a biotóp, jellemző a vízkedvelő fajok magas aránya. Karakterfajai holarktikus és euroszibériai fajok, amelyek a kedvezőtlenebb nyári időszakban a vízben bővebb pontokon kumulatív eloszlást mutatnak.

2. mintaterület: Az égeres talaján a korábbi években összegyült törmelék rendszeres vízborításra utal. A vizsgált időszakban a terület száraz volt. Az itt élő ritka, védett, apró termetű védett csigafajok populációjának fennmaradása szükségessé teszi az élőhely rekonstrukcióját. Malakológiai szempontból a jelenlegi, erősen kiszáradt állapotában is a természetvédelmi terület egyik legértékesebb része.

4. mintaterület: Faunája a rendszeres kaszálás okozta hírtelen száradás következtében szegényebb, bár fajösszetételében az állandó vízellátású terület élővilágára emlékeztet.

3., 5. és 9. mintaterület: A homoktakarón kialakult száraz sztyepptársulásokban délies elterjedésü, szárazságtürő fajok az uralkodóak. Érdekes színező elem a fenyőerdő vastag avarjában a nagyszámú Nesovitrea hammonis előfordulása.

7. és 10. mintaterület: A Vizgyüjtö-árokból előkerült molluszkum a magasabb térszínek erdőtársulásainak faunáját reprezentálja, míg a Tetves-patak domináns fajai egyértelmüen a patak melletti kaszált területekről származnak. A fajok magas száma a vízgyüjtö-terület nagyságának és a felsőbb szakaszokon levő kis számú természetes szürönek köszönhetö.

8. mintaterület: A homokpuszta melletti száraz fenyőerdő erősen bolygatott, faunája szegényes, az itt deponált háztartási hulladék alól számos meztelencsiga került elö.

11. mintaterület: A Tetves-patak vizsgált szakaszán gyüjtött iszapminta szegényes vízi faunát mutat. A patak vízhozama erősen ingadozó, magas víz esetén közvetítője lehet a felsőbb szakaszon élö puhatestüeknek. Erre utal a kaszált területek felső talajrétegében fellelt számos vizicsiga héjmaradvány.

12. mintaterület: A vizsgált terület száraz sztyepprét és fiatal tölgyes mozaikja. A lombos fajok arányát növelve értékes csigacönózis alakulhat ki a területen.

\section{Összefoglalás}

A Látrányi Puszta Természetvédelmi Területröl az elmúlt 3 évben 65 molluszka került elö. Közülük 3 faj védett, a Vertigo moulinsiana populáció fennmaradásának feltétele a vizes élőhelyek megmaradása, az égeres menti területek kaszálásának mellözése. Jelen van 2 invázív puhatestü is, amelyek visszaszorítására nincs hatékony módszer. Az élöhelyek mozaikossága miatt a puhatestü fauna is eltérő karakterü fajokból áll, amelyek sok esetben egymás közvetlen közelében fordulnak elö. A populációk hosszú távú fennmaradása érdekében szükséges a terület egykori bővebb vízellátottságának helyreállítása, a terület határainak kibővítése. 


\section{Irodalom}

ÁDÁM L., MARosı S., SzILÁRD J. 1981: A Dunántúli dombság. (Dél-Dunántúl). - Magyarország tájföldrajza 4. - Akad Kiadó, Budapest

BACsó N., KAKAS J., TAKẢCS L. 1959: Magyarország éghajlata Budapest

Document Url 1.: http:: //www.unep-wcmc.org/species/animals/index

ERDÉLYI M. 1961-1962: Külsö-Somogy vízföldtana. Hidrológiai Közlöny 41.-42.

Graber, C. \& SuTER, H. 1995: Schneckenbekämpfung ohne Gift. Verlag Frank-Kosmos, Stuttgart.

KLEIN K., 1992: Somogy megyei erdőtípusok csigaegyütteseinck vizsgálata - Malakológiai Tájékoztató 11: 59 68.

Pokryszko, B. 1990: The Vertiginidae of Poland (Gastropoda: Pulmonata: Pupilloidea) - a systematic monograph. Annales Zoologici, vol. 43, no 8, pp. 257.

REÖTHY F. 1986: Balatonföldvár. A Balatonföldvári Tanács kiadványa

Soós L. 1943: A Kárpát-medence Mollusca faunája - Budapest: pp.138.

VARga A. - BÁnKútı K. - KovÁcs T. 1995: Az Arion lusitanicus Mabille, 1868 magyarországi terjedése Malakológiai Tájékoztató 14: 17-20.

\section{Basic malacological (Mollusca) research of the Látrányi Puszta Nature Conservation Area.}

\section{ZOLTÁN HÉRA}

In the past three years, 65 molluscs species were found in the Látrányi Puszta Nature Conservation Area. Three of the collected species are protected: Vertigo angustior Jeffreys, 1830, Vertigo moulinsiana (Dupuy, 1849), Helix pomatia Linnaeus, 1758.

The protection of wet habitats and suspension of regular mowing and grazing on the areas near alder swamps/fens are of crucial importance for the survival of Vertigo moulinsiana. Two invasive molluscs, Potamopyrgus antipodarum (Gray, 1843) and Arion lusitanicus Mabille, 1868 can also be found here and there is no effective method known to suppress them. Due to the scattered localities, the mollusc fauna consists of species with diverse characteristics, which in most cases occur in close vicinity. In order to maintain the population in the long run, it is highly important to restore the original rich water supply and extend of the area of the habitats.

The collected material was placed in the care of the Natural History Department of Somogy County Museum. 